\title{
Effects of Addition of Essential Oils and Monensin Premix on Digestion, Ruminal Fermentation, Milk Production, and Milk Composition in Dairy Cows ${ }^{1}$
}

\author{
C. Benchaar, ${ }^{* 2}$ H. V. Petit, ${ }^{*}$ R. Berthiaume,${ }^{*}$ T. D. Whyte,$t^{3}$ and P. Y. Chouinard \\ *Dairy and Swine Research and Development Centre, Agriculture and Agri-Food Canada, Sherbrooke, Quebec, Canada J1M 1 Z3 \\ †Department of Plant and Animal Sciences, Nova Scotia Agricultural College, Truro, Nova Scotia, Canada B2N 5E3 \\ ‡Département des Sciences Animales, Université Laval, Quebec, Quebec, Canada G1K 7P4
}

\begin{abstract}
Four ruminally cannulated, lactating Holstein cows were used in a $4 \times 4$ Latin square design (28-d periods) with a $2 \times 2$ factorial arrangement of treatments to study the effects of dietary addition of essential oils $(0$ vs. $2 \mathrm{~g} / \mathrm{d}$; EO) and monensin (0 vs. $350 \mathrm{mg} / \mathrm{d}$; MO) on digestion, ruminal fermentation characteristics, milk production, and milk composition. Intake of dry matter averaged $22.7 \mathrm{~kg} / \mathrm{d}$ and was not significantly affected by dietary additives. Apparent digestibilities of dry matter, organic matter, neutral detergent fiber, and starch were similar among treatments. Apparent digestibility of acid detergent fiber was increased when diets were supplemented with EO (48.9 vs. $46.0 \%)$. Apparent digestibility of crude protein was higher for cows fed MO compared with those fed no MO (65.0 vs. $63.6 \%$ ). Nitrogen retention was not changed by additive treatments and averaged $27.1 \mathrm{~g} / \mathrm{d}$ across treatments. Ruminal $\mathrm{pH}$ was increased with the addition of $\mathrm{EO}$ (6.50 vs. 6.39). Ruminal ammonia nitrogen $\left(\mathrm{NH}_{3}-\mathrm{N}\right)$ concentration was lower with MO-supplemented diets compared with diets without MO (12.7 vs. $14.3 \mathrm{mg} / 100 \mathrm{~mL}$ ). No effect of $\mathrm{EO}$ and $\mathrm{MO}$ was observed on total volatile fatty acid concentrations and molar proportions of individual volatile fatty acids. Protozoa counts were not affected by EO and MO addition. Production of milk and $4 \%$ fat-corrected milk was similar among treatments (33.6 and $33.4 \mathrm{~kg} / \mathrm{d}$, respectively). Milk fat content was lower for cows fed MO than for cows fed diets without MO (3.8 vs. $4.1 \%)$. The reduced milk fat concentration in cows fed MO was associated with a higher level of trans10 18:1, a potent inhibitor of milk fat synthesis. Milk
\end{abstract}

\footnotetext{
Received January 25, 2006.

Accepted June 13, 2006.

${ }^{1}$ Contribution number 893 from the Dairy and Swine Research and Development Centre, PO Box 90, STN Lennoxville, Sherbrooke, QC, Canada J1M 1 Z3.

${ }^{2}$ Corresponding author: benchaarc@agr.gc.ca

${ }^{3}$ Present address: Department of Agricultural, Food and Nutritional Science, University of Alberta, Edmonton, AB, Canada T6G $2 \mathrm{P} 5$.
}

urea nitrogen concentration was increased by MO supplementation, but this effect was not apparent when MO was fed in combination with $\mathrm{EO}$ (interaction $\mathrm{EO} \times$ $\mathrm{MO})$. Results from this study suggest that feeding EO $(2 \mathrm{~g} / \mathrm{d})$ and $\mathrm{MO}(350 \mathrm{mg} / \mathrm{d})$ to lactating dairy cows had limited effects on digestion, ruminal fermentation characteristics, milk production, and milk composition.

Key words: essential oil, monensin, metabolism, dairy cow

\section{INTRODUCTION}

In recent years, public concern over the routine use of feed antibiotics and growth promoters in livestock production has increased. Accordingly, there is greater interest in using plants and plant extracts as alternatives to feed antibiotics to manipulate ruminal fermentation and improve feed efficiency in ruminants. Among these products, essential oils (EO) are attracting much attention. Essential oils are the naturally occurring secondary metabolites and volatile components that can be extracted from plants by distillation methods, mainly steam distillation. Chemically, EO are complex mixtures of mono- and sesquiterpenes and biogenically related phenolics or monophenols (Hummelbrunner and Isman, 2001). Essential oils have antimicrobial activities against gram-negative and gram-positive bacteria (Conner, 1993), which have been related to a number of small terpenoid and phenolic compounds (Helander et al., 1998). Recently, a number of studies have been published on the effects of EO on rumen microorganisms and rumen metabolism. Most of these studies are short-term in vitro culture incubations (McIntosh et al., 2003; Cardozo et al., 2004; Busquet et al., 2005; Castillejos et al., 2005) or in situ incubations (Benchaar et al., 2003a; Molero et al., 2004; Newbold et al., 2004), and only a few (Benchaar et al., 2003b; Newbold et al., 2004; Benchaar et al., 2006) have been conducted in vivo to evaluate the influence of $\mathrm{EO}$ on ruminant metabolism and performance.

Monensin (MO), a monocarboxylic acid ionophore is widely used in ruminant diets, and its positive effects 
on feed efficiency, nitrogen, and energy utilization are well known (Plaizier et al., 2000; Tedeschi et al., 2003). Recently, the use of MO premix (Rumensin Premix; Elanco Division, Eli Lilly Canada Inc., Guelph, Ontario, Canada) has been approved in Canada in dairy cow rations at a level of $16 \mathrm{mg} / \mathrm{kg}$ of DM. Several reports have been published on the effects of MO supplementation on the digestion, metabolism, and milk production of dairy cows, but only a few studies have investigated the effectiveness of MO fed at the dose of $16 \mathrm{mg} / \mathrm{kg}$ of DM on feed intake, nutrient utilization, milk production, and milk composition (Ramanzin et al., 1997; Phipps et al., 2000; Ruiz et al., 2001). Essential oils have been shown to inhibit the activity of ruminal bacteria that are sensitive to MO (McIntosh et al., 2003; Newbold et al., 2004). Therefore, this study was undertaken to determine the effects of 2 antimicrobial agents, $\mathrm{EO}$ and $\mathrm{MO}$, on digestion, ruminal fermentation characteristics, milk production, and milk composition in lactating dairy cows.

\section{MATERIALS AND METHODS}

\section{Cows and Diets}

Four lactating Holstein cows fitted with ruminal cannulas (10 cm; Bar Diamond Inc., Parma, ID) were used in a $4 \times 4$ Latin square design (28-d periods) balanced for residual effect with a $2 \times 2$ factorial arrangement of treatments. The cows averaged $98 \pm 7$ DIM at the start of the experiment with an average BW of $662 \pm$ $52 \mathrm{~kg}$ and an average BCS of $2.85 \pm 0.25$ (5-point scale). Treatments were EO supplementation (with: +EO vs. without:-EO) and MO supplementation (with: +MO vs. without:-MO). The EO supplement (Crina Ruminants; Akzo Nobel Surface Chemistry Ltd., Crina SA, Gland, Switzerland) was provided at the level of $2 \mathrm{~g} / \mathrm{d}$ and consisted of a mixture of natural and nature-identical EO components that included thymol, eugenol, vanillin, and limonene (McIntosh et al., 2003). Previous studies conducted in our laboratory showed that feeding the same EO supplement to dairy cows at the dose of 750 $\mathrm{mg} / \mathrm{d}$ had no effect on digestion, ruminal fermentation, milk production, or milk composition (Benchaar et al., 2003a,b), thus suggesting that the dose of $750 \mathrm{mg} / \mathrm{cow}$ per $d$ may have been too low to alter ruminal fermentation and metabolism. Accordingly, a higher dosage was used in the present study to assess the effectiveness of EO as rumen modifiers. Monensin (Rumensin premix; Elanco Division, Eli Lilly Canada Inc.) was incorporated into the diet at the dose of $16 \mathrm{mg} / \mathrm{kg}$ of DM (350 $\mathrm{mg} / \mathrm{d}$ ), which corresponds to the dose recommended by the manufacturer (Elanco Canada) for the use of MO premix in dairy cow rations. The ingredient and chemical composition of the TMR used in the experiment is
Table 1. Ingredients and chemical composition of the TMR

\begin{tabular}{lc}
\hline Composition & Amount \\
\hline Ingredient, \% of DM & \\
Grass silage & 35.8 \\
Corn silage & 12.4 \\
Corn, ground & 30.3 \\
Corn gluten meal & 4.5 \\
Soybean meal, 48\% CP & 4.5 \\
Beet pulp & 6.1 \\
Wheat bran & 3.1 \\
Limestone & 0.9 \\
Ca 17\%:P 21\% & 0.5 \\
Magnesium oxide & 0.2 \\
Sodium bicarbonate & 1.2 \\
Salt ${ }^{1}$ & 0.3 \\
Selenium & 0.1 \\
Vitamin A, D, and E premix & \\
Chemical & 0.1 \\
DM, \% & \\
OM, \% of DM & 43.0 \\
CP, \% of DM & 92.1 \\
NDF, \% of DM & 18.6 \\
ADF, \% of DM & 35.8 \\
Starch, \% of DM & 24.4 \\
Ether extract, \% of DM & 20.4 \\
NE, Mcal/kg of DM ${ }^{3}$ & 3.94 \\
\hline
\end{tabular}

${ }^{1}$ Contained (per kg): $965 \mathrm{~g}$ of $\mathrm{NaCl} ; 7,500 \mathrm{mg}$ of $\mathrm{Zn} ; 5,000 \mathrm{mg}$ of $\mathrm{Mn} ; 2,500 \mathrm{mg}$ of $\mathrm{Cu} ; 1,600 \mathrm{mg}$ of $\mathrm{Fe} ; 70 \mathrm{mg}$ of I; and $40 \mathrm{mg}$ of Co.

${ }^{2}$ Contained (per kg): 500,000 IU of vitamin A; 50,000 IU of vitamin $\mathrm{D}$, and $550 \mathrm{IU}$ of vitamin $\mathrm{E}$.

${ }^{3}$ Calculated using published values of feed ingredients (NRC, 2001).

shown in Table 1. Cows were fed for ad libitum intake, housed in individual tie stalls, and had free access to water during the experiment. Adaptation to experimental treatments was from d 1 to 14 , in sacco ruminal degradability measurement from d 14 to 18 , ruminal sampling on d 17, and milk yield and sampling and total fecal and urine collection from d 21 to 28. Cows were cared for in accordance with the guidelines of the Canadian Council on Animal Care (CCAC, 1993).

\section{Feed Intake and BW}

Diets were offered in equal amounts twice daily (0800 and $1600 \mathrm{~h}$ ). Feed consumption was recorded daily by weighing feeds offered to and refused by the cows and data from d 14 to 28 were included in the statistical analysis. Samples of TMR, feed ingredients, and orts were collected daily and kept frozen. Samples were composited by period, dried at $55^{\circ} \mathrm{C}$ for $48 \mathrm{~h}$, ground through a 1-mm screen Wiley mill (standard model 4; Arthur M. Thomas, Philadelphia, PA), and analyzed for DM, $\mathrm{OM}$, total N, NDF, ADF, starch, lipids, and fatty acid (FA) composition. Body weight was determined at the beginning and the end of each experimental period after the a.m. milking on 2 consecutive days. 


\section{Apparent Total-Tract Digestibility and N Balance}

On d 21 of each experimental period, cows were fitted with harnesses and tubes allowing the collection of feces and urine separately. For 7 consecutive days, feces were weighed and mixed daily, and a representative sample $(2 \%)$ was taken, stored at $-20^{\circ} \mathrm{C}$, and subsequently thawed, dried at $55^{\circ} \mathrm{C}$ for $48 \mathrm{~h}$, and ground through a 1-mm screen (Wiley mill) for chemical analysis. Total urine was collected daily into stainless-steel containers and acidified with $\mathrm{H}_{2} \mathrm{SO}_{4}(50 \% \mathrm{vol} / \mathrm{vol})$ to maintain $\mathrm{pH}$ $<2.0$. A representative sample $(2 \%)$ was taken and kept frozen at $-20^{\circ} \mathrm{C}$ until analysis.

\section{Milk Production and Milk Composition}

Cows were milked twice daily in their stalls (0500 and $1700 \mathrm{~h}$ ), and milk yield was recorded at each milking. During the last week of each 28-d period, milk samples were taken from each cow at each milking, pooled on a yield basis, and stored at $+4^{\circ} \mathrm{C}$ with a preservative (bronopol-B2) until analyzed for fat, protein, urea $\mathrm{N}$, lactose, and total solids. Composite milk samples without preservative were frozen at $-20^{\circ} \mathrm{C}$ until analyzed for the milk FA profile.

\section{Ruminal Fermentation Characteristics}

Ruminal fluid was collected from the anterior dorsal, anterior ventral, medium ventral, posterior dorsal, and posterior ventral locations within the rumen at $0,1,2$, 4,6 , and $8 \mathrm{~h}$ after the $0800 \mathrm{~h}$ feeding. Samples (250 $\mathrm{mL} / \mathrm{site}$ ) were withdrawn using a syringe screwed to a stainless-steel tube ending with a probe covered by fine metal mesh (RT Rumen Fluid Collection Tube, Bar Diamond Inc.). Ruminal fluid $\mathrm{pH}$ was measured immediately after sampling (Accumet $\mathrm{pH}$ meter; Fisher Scientific, Montreal, Quebec, Canada), and samples were acidified to $\mathrm{pH} 2$ with $50 \% \mathrm{H}_{2} \mathrm{SO}_{4}$ and frozen at $-20^{\circ} \mathrm{C}$ for later determination of VFA and $\mathrm{NH}_{3}-\mathrm{N}$ concentrations.

\section{Protozoa Enumeration}

Protozoa counts were carried out on ruminal fluid samples collected $2 \mathrm{~h}$ after the a.m. feeding. Ruminal fluid (1 L) and solid digesta $(500 \mathrm{~g})$ samples were collected from different locations of the rumen of each cow. Samples were mixed thoroughly, and subsamples of 500 $\mathrm{mL}$ of ruminal fluid and $250 \mathrm{~g}$ of solid digesta were blended anaerobically under oxygen-free $\mathrm{CO}_{2}$ and strained through 2 layers of cheesecloth. A $3-\mathrm{mL}$ portion of the ruminal fluid strained was preserved using $3 \mathrm{~mL}$ of methyl green formalin-saline solution for protozoa enumeration (Ogimoto and Imai, 1981). Protozoa sam- ples were stored at room temperature in the dark until counted.

\section{In Sacco Degradability}

Ruminal degradabilities of soybean meal, corn grain, and grass silage were determined using the nylon bag procedure, and these feeds were chosen to represent feed ingredients commonly used as sources of protein, starch (cereals), and fiber (forages), respectively. Feeds were freeze-dried and ground through a 2-mm screen in a Wiley mill (standard model 4; Arthur M. Thomas) and 5-g (DM basis) samples were weighed in duplicate into polyester bags $(17 \times 9 \mathrm{~cm} ; 53 \mu \mathrm{m}$ pore size) made of monofilament PeCAP polyester (B. \& S. H. Thompson, Ville Mont-Royal, Quebec, Canada). Bags were placed in large mesh $(20 \times 30 \mathrm{~cm})$ retaining sacs with $3 \times 5$ $\mathrm{mm}$ pores that allowed ruminal fluid to circulate freely. Bags were soaked in $37^{\circ} \mathrm{C}$ water for 5 min before being placed in duplicate in the ventral sac of the rumen for $0,8,16,24$, and $48 \mathrm{~h}$ (soybean meal); $0,8,16,24,48$, and $72 \mathrm{~h}$ (corn grain); and $0,8,16,24,48,72$, and 96 $\mathrm{h}$ (grass silage). On removal from the rumen, bags were immediately immersed in ice water to stop microbial activity, then thoroughly rinsed with cold tap water and frozen at $-20^{\circ} \mathrm{C}$. Afterward, bags were thawed, washed in a domestic washing machine, and dried at $55^{\circ} \mathrm{C}$ for $48 \mathrm{~h}$. Bags and contents were weighed, and residues were ground through a 1-mm screen in a Wiley mill and stored for subsequent analysis of DM (soybean meal, corn grain, and grass silage), total $\mathrm{N}$ (soybean meal), NDF and ADF (grass silage), and starch (corn grain). Zero-time disappearance was obtained by washing unincubated bags in a similar manner.

Kinetics of DM, CP, ADF, NDF, and starch degradabilities were calculated using a nonlinear model (McDonald, 1981). The NLIN procedure of SAS (SAS Institute, 2000) was used to fit the following model:

$$
p=a+b\left[1-e^{-c(t-L)}\right] \text { for } t>L
$$

where $p$ is the disappearance rate at time $t$, $a$ is an intercept representing the fraction of the constituent that is rapidly degradable (\%), $\mathrm{b}$ is the fraction of the constituent that is slowly degradable (\%), $\mathrm{c}$ is the fractional degradation rate of disappearance of fraction $b$ in the rumen $(\% / h), t$ is the time of incubation $(\mathrm{h})$, and $\mathrm{L}$ is the lag time (h).

Effective ruminal degradabilities (ERD) of DM, CP, $\mathrm{ADF}, \mathrm{NDF}$, and starch were calculated using the equation:

$$
\mathrm{ERD}=\mathrm{a}+[\mathrm{bc} /(\mathrm{c}+\mathrm{kp})] \times \mathrm{e}^{(-\mathrm{kpL})},
$$


where $\mathrm{kp}$ is the ruminal passage rate, calculated at $5.0 \% / \mathrm{h}$ for silage and $6.1 \% / \mathrm{h}$ for soybean meal and corn grain, from the equations developed by the NRC (2001) for wet forages (silage) and concentrates.

\section{Chemical Analyses}

Analytical DM content of TMR, orts, and fecal samples was determined by oven drying at $105^{\circ} \mathrm{C}$ for $48 \mathrm{~h}$ (AOAC, 1990; Method 930.15). Ash content of the TMR, orts, and feces was determined by incineration at $550^{\circ} \mathrm{C}$ overnight, and the $\mathrm{OM}$ content was calculated as the difference between 100 and the percentage of ash (AOAC, 1990; Method 942.05). The total N content of TMR, orts, and feces was determined by thermal conductivity (LECO model FP-428 Nitrogen Determinator, LECO, St. Joseph, MI). Crude protein was calculated as $\mathrm{N} \times 6.25$. The concentration of NDF in TMR, orts, and feces was determined as described by Van Soest et al. (1991) without the use of sodium sulfite and with the inclusion of heat-stable $\alpha$-amylase. The ADF content in TMR, orts, and feces was determined according to AOAC (1990; Method 973.18). The NDF and ADF procedures were adapted for use in an $\mathrm{ANKOM}^{200}$ Fiber Analyzer (ANKOM Technology Corp., Fairport, NY). The starch concentration of TMR, orts, and feces was determined colorimetrically using a commercial kit (\#10 207 748 035; Boehinger Mannheim, Burgessville, Ontario, Canada; Keppler and Decker, 1974). The ether extract content in TMR and orts samples was determined using a Soxlec system HT6 apparatus (Tecator, Fisher Scientific) according to AOAC Method 920.39 (AOAC, 1990). The concentration of $\mathrm{N}$ in acidified urine samples was determined by micro-Kjeldahl analysis (AOAC, 1990; Method 960.52). Concentrations of $\mathrm{NH}_{3}-\mathrm{N}$ and VFA in ruminal fluid were analyzed by colorimetry using the phenyl-hypochlorite reaction (Weatherburn, 1967) and by GLC (Varian 3700; Varian Specialities Ltd., Brockeville, Ontario, Canada), respectively. Protozoa were enumerated microscopically in a Levy-Hausser counting chamber (Hausser Scientific, Horsham, PA). Each sample was counted twice, and if the average of the duplicates differed by more than $10 \%$, the counts were repeated. Protein, fat, lactose, total solids, and urea $\mathrm{N}$ concentrations in milk samples were analyzed by infrared spectrophotometer (System 4000 MilkoScan; Foss Electric, Hillerød, Denmark; AOAC, 1990). Milk FA composition was determined by GLC (HP 5890A Series II; Hewlett-Packard, Palo Alto, CA) according to the method described by Chouinard et al. (1997). Composition of FA in feed samples was analyzed according to the procedure of Sukhija and Palmquist (1988).

\section{Statistical Analysis}

Data were analyzed using the MIXED procedure of SAS (SAS Institute, 2000) according to the model: $\mathrm{Y}_{i j k}=$ $\mu+\mathrm{a}_{i}+\beta_{j}+\tau_{k}+\mathrm{e}_{i j k}$, where $\mathrm{Y}_{i j k}$ is the response variable, $\mu$ is the overall mean, $a_{i}$ is the random effect of cow $i$, $\beta_{j}$ is the effect of period $j, \tau_{k}$ is the effect of treatment $k$, and $\mathrm{e}_{i j k}$ is the random residual error. The residual effect was initially included in the model but was removed because it was not significant. For the statistical analysis of ruminal fermentation characteristics $(\mathrm{pH}$, VFA, $\mathrm{NH}_{3}-\mathrm{N}$ ), sampling time and sampling time $\times$ treatment were added to the model and analyzed as repeated measures using PROC MIXED, and the compound symmetry was used as the covariance structure. Factorial contrasts were used to test the main effects of EO supplementation (+EO vs. -EO), MO supplementation (+MO vs. $-\mathrm{MO})$, and their interaction. Results are reported as least squares means \pm SEM. Significance was declared at $P \leq 0.05$ and a trend at $P<0.10$ unless otherwise stated.

\section{RESULTS AND DISCUSSION}

\section{Intake of DM and BW}

Feeding EO alone decreased DMI whereas feeding EO in the presence of MO increased DMI, which tended $(P=0.06)$ to result in an interaction when DMI was expressed in kilograms per day, and the interaction was significant when DMI was expressed as a percentage of BW (Table 2). Benchaar et al. (2003b) observed no change in DMI when lactating dairy cows were fed a mixture of EO alone $(750 \mathrm{mg} / \mathrm{d}$; Crina Ruminants), whereas feeding greater amounts ( 2 and $4 \mathrm{~g} /$ head per d) of a blend of EO compounds (Vertan; IDENA, Sautron, France) increased DMI of growing beef cattle fed silagebased diets (Benchaar et al., 2006). Although the effects of including MO as a premix or controlled-release capsule in dairy cattle rations have been extensively investigated, results have been variable in terms of DMI. The addition of MO either did not influence (Ramanzin et al., 1997; Broderick, 2004) or decreased (Sauer et al., 1998) the DMI of lactating dairy cows. Tedeschi et al. (2003) speculated that the variability between studies is probably due to differences in the stage of lactation and that a reduction in DMI is a consequence of animals eating to their energy requirement. When cows are in positive energy balance (late lactation or dry cows), supplementation of the diet with MO may increase the energy available per unit of feed consumed (Mcal/d), thus resulting in lower DMI. On the other hand, when cows are in negative energy balance (early lactation) the additional energy available because of MO supplementation is used to improve performance, reduce body 
Table 2. Effects of essential oils (EO) and monensin (MO) on DMI and initial and final BW of lactating dairy cows

\begin{tabular}{|c|c|c|c|c|c|c|c|c|}
\hline \multirow[b]{2}{*}{ Item } & \multicolumn{2}{|c|}{$-\mathrm{EO}$} & \multicolumn{2}{|c|}{$+\mathrm{EO}$} & \multirow[b]{2}{*}{ SEM } & \multicolumn{3}{|c|}{ Contrast $^{1}(P=)$} \\
\hline & $-\mathrm{MO}$ & $+\mathrm{MO}$ & $-\mathrm{MO}$ & $+\mathrm{MO}$ & & $\mathrm{EO}$ & MO & Inter \\
\hline \multicolumn{9}{|l|}{ DMI } \\
\hline $\mathrm{kg} / \mathrm{d}$ & 22.9 & 22.3 & 22.5 & 23.1 & 0.26 & 0.55 & 0.98 & 0.06 \\
\hline$\%$ of $\mathrm{BW}$ & 3.41 & 3.31 & 3.36 & 3.44 & 0.04 & 0.29 & 0.71 & 0.04 \\
\hline \multicolumn{9}{|l|}{ BW, kg } \\
\hline Initial & 669 & 675 & 666 & 665 & 3 & 0.09 & 0.39 & 0.25 \\
\hline Final & 675 & 677 & 677 & 679 & 2 & 0.19 & 0.17 & 0.96 \\
\hline Change, kg/d & 0.22 & 0.07 & 0.38 & 0.50 & 0.12 & 0.05 & 0.92 & 0.32 \\
\hline
\end{tabular}

${ }^{1} P$-value for factorial contrasts: essential oils (+EO vs. $\left.-\mathrm{EO}\right)$, monensin (+MO vs. $\left.-\mathrm{MO}\right)$, and the interaction between EO and MO (Inter).

reserve losses, or both (Tedeschi et al., 2003). Cows used in the present experiment would have been in positive energy balance because they averaged 98 DIM at the initiation of the experiment, but they did not show any decrease in DMI. Therefore, although feeding MO alone could have a negative impact on the DMI of cows in a positive energy balance, as hypothesized by Tedeschi et al. (2003), feeding EO at the same time could contribute to alleviating the negative effect of MO. These results would suggest that the addition of both EO and MO simultaneously in ruminant diets stimulates DMI compared with feeding either one separately.

Initial and final BW averaged 669 and $677 \mathrm{~kg}$, respectively, and they were similar among treatments. However, BW gain was higher for cows fed EO than for those fed no EO (0.44 vs. $0.15 \mathrm{~kg} / \mathrm{d}$, respectively).

\section{Apparent Total-Tract Digestibility and N Balance}

There was no interaction between EO and MO for digestibility of nutrients (Table 3). Apparent digestibili- ties of DM, OM, and NDF averaged, respectively, 66.6, 68.3 , and $47.9 \%$, and they were not influenced by EO and MO supplementation. Apparent CP digestibility averaged $64.1 \%$ and did not differ between cows fed EO and those not receiving EO. This would agree with the results of Castillejos et al. (2005), who observed no change in DM, OM, NDF, and CP digestibility when a Crina Ruminants EO mixture was added at the dose of $3.8 \mathrm{mg} / \mathrm{L}$ of ruminal fluid in continuous-culture fermenters. The digestibility of NDF was not affected in lactating dairy cows supplemented with a mixture of EO compounds (Benchaar et al., 2003b). In the current study, digestibility of ADF was significantly increased by 3 percentage points when diets were supplemented with EO (48.9 vs. $46.0 \%)$. However, ruminal in sacco degradation of $\mathrm{ADF}$ was not affected by $\mathrm{EO}$ addition (see subsequent discussion; Table 7), suggesting that EO supplementation altered total-tract digestibility by enhancing ADF digestion at postruminal sites. The digestibility of $\mathrm{ADF}$ was not changed by $\mathrm{EO}$ addition in lactating dairy cow diets (Benchaar et al., 2003b) or in continuous-culture fermenters (Castillejos et al., 2005).

Table 3. Effects of essential oils (EO) and monensin (MO) on total-tract digestibility and $\mathrm{N}$ balance in lactating dairy cows

\begin{tabular}{|c|c|c|c|c|c|c|c|c|}
\hline \multirow[b]{2}{*}{ Item } & \multicolumn{2}{|c|}{$-\mathrm{EO}$} & \multicolumn{2}{|c|}{$+\mathrm{EO}$} & \multirow[b]{2}{*}{ SEM } & \multicolumn{3}{|c|}{ Contrast $^{1}(P=)$} \\
\hline & $-\mathrm{MO}$ & $+\mathrm{MO}$ & $-\mathrm{MO}$ & $+\mathrm{MO}$ & & $\mathrm{EO}$ & MO & Inter \\
\hline \multicolumn{9}{|c|}{ Digestibility, \% } \\
\hline DM & 65.9 & 67.1 & 66.7 & 66.8 & 0.4 & 0.48 & 0.13 & 0.16 \\
\hline $\mathrm{OM}$ & 67.5 & 68.8 & 68.4 & 68.5 & 0.4 & 0.46 & 0.15 & 0.17 \\
\hline $\mathrm{CP}$ & 63.0 & 65.0 & 64.3 & 64.9 & 0.6 & 0.30 & 0.05 & 0.28 \\
\hline NDF & 47.2 & 47.1 & 47.9 & 49.3 & 0.8 & 0.12 & 0.42 & 0.36 \\
\hline $\mathrm{ADF}$ & 46.9 & 45.2 & 48.8 & 49.1 & 1.0 & 0.03 & 0.49 & 0.36 \\
\hline Starch & 96.0 & 96.8 & 97.0 & 97.0 & 0.2 & 0.03 & 0.10 & 0.12 \\
\hline \multicolumn{9}{|c|}{$\mathrm{N}$ balance, $\mathrm{g} / \mathrm{d}$} \\
\hline $\mathrm{N}$ intake & 691 & 674 & 682 & 696 & 7 & 0.39 & 0.89 & 0.06 \\
\hline $\mathrm{N}$ in feces & 256 & 235 & 243 & 243 & 6 & 0.71 & 0.15 & 0.14 \\
\hline $\mathrm{N}$ in urine & 224 & 219 & 228 & 244 & 12 & 0.27 & 0.63 & 0.41 \\
\hline $\mathrm{N}$ in milk & 193 & 186 & 181 & 184 & 7 & 0.37 & 0.75 & 0.49 \\
\hline $\mathrm{N}$ retained & 18 & 35 & 30 & 26 & 11 & 0.90 & 0.58 & 0.36 \\
\hline
\end{tabular}

${ }^{1} P$-value for factorial contrasts: essential oils (+EO vs. $\left.-\mathrm{EO}\right)$, monensin (+MO vs. $\left.-\mathrm{MO}\right)$, and the interaction between $\mathrm{EO}$ and $\mathrm{MO}$ (Inter). 
Apparent digestibility of ADF was not affected by MO supplementation. Plaizier et al. (2000) reported that MO increased the apparent digestibilities of NDF and $\mathrm{ADF}$ in cows fed high-forage diets, whereas there was no effect on fiber digestion in cows fed high-concentrate diets.

Apparent digestibility of starch was slightly but significantly $(P<0.05)$ higher in cows fed EO compared with those fed diets not supplemented with EO (97.0 vs. 96.4\%). No effect of MO supplementation was observed on the apparent digestibility of starch. This would agree with the results of Ali-Haïmoud et al. (1995), who observed no change in total-tract digestibility of starch in lactating cows supplemented with MO.

Apparent digestibility of CP was higher for cows fed diets supplemented with MO compared with those not receiving MO (65.0 vs. $63.6 \%$ ). Earlier studies showed inconsistent effects of $\mathrm{MO}$ on $\mathrm{N}$ digestibility in dairy cows. For example, Plaizier et al. (2000) reported an increase in $\mathrm{N}$ digestibility when early lactating dairy cows were fed MO in the postcalving period, whereas Ali-Haïmoud et al. (1995) observed no effect of MO on $\mathrm{N}$ digestibility in lactating dairy cows. Discrepancies between studies could partly be due to differences in diet composition. According to Plaizier et al. (2000), $\mathrm{MO}$ administration increases $\mathrm{N}$ digestibility in cows fed high-concentrate diets, whereas it has no effect in those fed high-forage diets. Diets used in the present experiment contained approximately $52 \%$ concentrate (Table 1 ), which would corroborate that hypothesis.

The interaction between $\mathrm{EO}$ and $\mathrm{MO}$ tended $(P=$ 0.06 ) to be significant for $\mathrm{N}$ intake (Table 3 ) as a result of differences in DMI (Table 2). Outputs of $\mathrm{N}$ in feces, urine, and milk were similar among treatments. As a result, retention of $\mathrm{N}$, expressed in grams per day, averaged $27.1 \mathrm{~g} / \mathrm{d}$ and was not affected by additive treatments. Data on the effect of $\mathrm{EO}$ on the retention of $\mathrm{N}$ by dairy cows are scarce. The retention of $\mathrm{N}$ was not affected in lactating dairy cows (Benchaar et al., 2003b) or in beef cattle (Benchaar et al., 2006) fed different dose levels of a mixture of EO compounds.

Monensin premix supplementation has increased $\mathrm{N}$ retention in postcalving cows, but not in precalving cows (Plaizier et al., 2000). The increased $\mathrm{N}$ retention has usually been explained by improved $\mathrm{N}$ digestibility (Tedeschi et al., 2003). Although CP digestibility was increased by MO supplementation in the present experiment (Table 3), $\mathrm{N}$ retention was similar between treatments. Assuming that the body tissue contains about $20 \%$ protein (NRC, 2001), the retention of $27.3 \mathrm{~g}$ of N/ d (i.e., $170.3 \mathrm{~g}$ of protein/d) should have resulted in a BW gain of $0.85 \mathrm{~kg} / \mathrm{d}$. Considering the inherent error associated with $\mathrm{N}$ balance studies (Spanghero and Kowalski, 1997), true $\mathrm{N}$ retention was likely overesti- mated, as illustrated by the modest BW change recorded (Table 2).

\section{Ruminal Fermentation Characteristics}

There was no interaction $(P<0.05)$ between sampling time and treatment on any measurement of ruminal fermentation characteristics; therefore, only dietary effects are reported (Table 4). No interaction between EO and MO supplementation was observed for ruminal fermentation characteristics. Ruminal $\mathrm{pH}$ was increased (6.50 vs. 6.39) by the addition of EO. Similarly, Benchaar et al. (2003a) reported that ruminal pH tended $(P=0.07)$ to increase in lactating dairy cows fed EO. These findings can be interesting for controlling ruminal $\mathrm{pH}$ when cows are fed high-grain diets and are at risk for developing acidosis.

Supplementation with MO tended $(P=0.08)$ to increase $(+0.09$ points $)$ ruminal $\mathrm{pH}$. Other studies reported a similar increase (Plaizier et al., 2000) or no effect (Ramanzin et al., 1997; Broderick, 2004) on ruminal $\mathrm{pH}$ when dairy cows were fed MO.

The addition of EO had no effect on ruminal fluid concentration of $\mathrm{NH}_{3}-\mathrm{N}$. This would agree with the results of Castillejos et al. (2005) and Busquet et al. (2005), who reported that $\mathrm{EO}$ had no influence on $\mathrm{NH}_{3}$ $\mathrm{N}$ concentration in continuous-culture fermenters. On the other hand, McIntosh et al. (2003) and Newbold et al. (2004) observed a reduction in the rate of $\mathrm{NH}_{3}-\mathrm{N}$ production when a $\mathrm{CN}$ acid hydrolysate (i.e., free AA) was incubated for 24 to $48 \mathrm{~h}$ in strained ruminal fluid collected from cows and sheep fed $1 \mathrm{~g}$ and $100 \mathrm{mg} / \mathrm{d}$ of a commercial mixture of EO compounds (Crina Ruminants), respectively. McIntosh et al. (2003) observed no further decrease in $\mathrm{NH}_{3}-\mathrm{N}$ production when $\mathrm{MO}$ was added in ruminal fluid incubations, suggesting that EO reduced ammonia production in ruminal fluid by inhibiting the activity of the same group of bacteria that is sensitive to MO. This group of bacteria, called hyperammonia-producing ("HAP") bacteria, was originally identified by Russell et al. (1988) and characterized as having high deaminative activity and as being responsible for a significant proportion of ammonia produced in the rumen. Benchaar et al. (2003a) observed no effect of $\mathrm{EO}$ on the $\mathrm{NH}_{3}-\mathrm{N}$ concentration in the rumen of lactating cows fed silage-based diets. This discrepancy between studies could be due to the procedure used (in vivo vs. in vitro) and therefore to the length of exposure of ruminal bacteria to EO (e.g., 24 to $48 \mathrm{~h}$ in vitro vs. 2 to 4 wk in vivo). Moreover, ruminal bacteria could adapt to EO, because Cardozo et al. (2004) and Busquet et al. (2005) have recently observed that the effects of different EO compounds on rumen microbial fermentation disappeared after $6 \mathrm{~d}$ of incubation in a continuous- 
Table 4. Effects of essential oils (EO) and monensin (MO) on fermentation characteristics and protozoa counts in the ruminal fluid of lactating dairy cows

\begin{tabular}{|c|c|c|c|c|c|c|c|c|}
\hline \multirow[b]{2}{*}{ Item } & \multicolumn{2}{|c|}{$-\mathrm{EO}$} & \multicolumn{2}{|c|}{$+\mathrm{EO}$} & \multirow[b]{2}{*}{ SEM } & \multicolumn{3}{|c|}{ Contrast $^{1}(P=)$} \\
\hline & $-\mathrm{MO}$ & $+\mathrm{MO}$ & $-\mathrm{MO}$ & $+\mathrm{MO}$ & & EO & MO & Inter \\
\hline $\mathrm{pH}$ & 6.33 & 6.44 & 6.46 & 6.53 & 0.04 & 0.04 & 0.08 & 0.69 \\
\hline $\mathrm{NH}_{3}-\mathrm{N}, \mathrm{mg} / 100 \mathrm{~mL}$ & 14.3 & 13.5 & 14.4 & 11.9 & 0.6 & 0.27 & 0.04 & 0.22 \\
\hline Total VFA, mM & 114.0 & 105.3 & 112.9 & 107.6 & 3.5 & 0.87 & 0.09 & 0.65 \\
\hline VFA, mol/100 mL & & & & & & & & \\
\hline Acetate (A) & 65.0 & 64.4 & 65.7 & 65.6 & 0.8 & 0.29 & 0.64 & 0.77 \\
\hline Propionate (P) & 22.4 & 23.5 & 22.1 & 23.3 & 0.6 & 0.66 & 0.10 & 0.93 \\
\hline Butyrate & 12.6 & 12.1 & 12.2 & 11.4 & 0.4 & 0.18 & 0.15 & 0.61 \\
\hline $\mathrm{A}: \mathrm{P}$ & 2.94 & 2.77 & 3.02 & 2.84 & 0.10 & 0.50 & 0.15 & 0.97 \\
\hline Protozoa, $\times 10^{5} / \mathrm{mL}$ & 5.13 & 4.88 & 4.45 & 5.06 & 0.61 & 0.70 & 0.76 & 0.51 \\
\hline
\end{tabular}

${ }^{1} P$-value for factorial contrasts: essential oils (+EO vs. $\left.-\mathrm{EO}\right)$, monensin (+MO vs. $\left.-\mathrm{MO}\right)$, and the interaction between EO and MO (Inter).

culture system. As a consequence, Cardozo et al. (2004) and Busquet et al. (2005) warned that data from shortterm in vitro fermentation studies may lead to erroneous conclusions and must be interpreted with caution. The variable effects of $\mathrm{EO}$ on the activities of ruminal bacteria could also be explained by the different doses used. Results from recent in vitro studies (Cardozo et al., 2004; Busquet et al., 2005; Busquet et al., 2006) revealed that EO are effective at high doses (300 to $3,000 \mathrm{mg} / \mathrm{L}$ of culture fluid) but at lower doses $(0.22$ to $2.2 \mathrm{mg} / \mathrm{L}$ of culture fluid), EO have little effect on rumen microbial fermentation. Assuming a rumen volume of $100 \mathrm{~L}$ for an adult lactating dairy cow, 300 to $3,000 \mathrm{mg}$ of EO per liter of rumen fluid would correspond to an intake of 30 to $300 \mathrm{~g}$ of $\mathrm{EO} / \mathrm{d}$, which is 30 to 300 times higher than the doses generally used in dairy cow rations (i.e., $1 \mathrm{~g} /$ cow per d). Therefore, longer term in vivo experiments are required to clearly establish the effects of EO supplementation at more normal feeding doses.

In the present study, $\mathrm{NH}_{3}-\mathrm{N}$ concentration in ruminal fluid was reduced (12.7 vs. $14.3 \mathrm{mg} / 100 \mathrm{~mL}$ ) for cows fed MO compared with those not supplemented with MO, which would agree with the results of Ali-Haïmoud et al. (1995) and Plaizier et al. (2000). In other studies, MO supplementation had no effect on the ruminal $\mathrm{NH}_{3}-$ N concentration of dairy cows (Ramanzin et al., 1997; Broderick, 2004).

Supplementation with EO had no effects on the ruminal total VFA concentrations and on molar proportions of individual VFA, as previously reported by Benchaar et al. (2003a) and Newbold et al. (2004). Castillejos et al. (2005) observed an increase in total VFA concentrations and no change in molar proportions of individual VFA when a mixture of EO compounds (Crina Ruminants) was added to continuous-culture fermenters.

The addition of MO had no effect on the proportions of individual VFA and on the acetate-to-propionate ratio. Ali-Haïmoud et al. (1995) observed no effect of MO supplementation on the acetate-to-propionate ratio, whereas Ruiz et al. (2001) reported that MO decreased the acetate-to-propionate ratio in dairy cows. These discrepancies between studies could be explained by differences in dietary inclusion levels of MO and to interactions between diet composition and MO. Broderick (2004) observed that the acetate-to-propionate ratio decreased when lactating cows were fed MO at $10 \mathrm{mg} / \mathrm{kg}$ of DM, but this change was much smaller than has been observed when using a higher dose of MO (Sauer et al., 1998). The level of MO fed in the present study (i.e., $16 \mathrm{mg} / \mathrm{kg}$ of $\mathrm{DM}$ ) was lower than the dose of 24 $\mathrm{mg} / \mathrm{kg}$ of DM administered in the study of Sauer et al. (1998). This would contribute to explaining the moderate changes in the acetate-to-propionate ratio observed in our study. Surber and Bowman (1998) reported that MO decreased the acetate-to-propionate ratio to a greater extent when beef steers were fed a barley-based diet than when they were fed a corn-based diet. Similarly, Jenkins et al. (2003) observed in vitro (i.e., continuous-culture fermenters) that MO had a greater effect on reducing the acetate-to-propionate ratio when the diet contained barley instead of corn grain. In the current study, the experimental diets contained $30 \%$ corn grain (Table 1), thus explaining the absence of significant effects of MO on the acetate-to-propionate ratio. The efficacy of MO in modifying the VFA pattern has also been shown to vary with diet composition, particularly with reference to the dietary proportion of concentrate. Ramanzin et al. (1997) reported that MO decreased the acetate-to-propionate ratio to a greater extent when lactating cows were fed a low-forage diet (50:50) than when they were fed a high-forage diet (70:30). However, no interaction between the forage-toconcentrate ratio of the diet and MO was found when Van Maanen et al. (1978) measured propionate production by the isotope-dilution technique in beef steers fed either a low- or a high-forage diet (20 vs. 70\%), 
Table 5. Effects of essential oils (EO) and monensin (MO) on the in sacco ruminal disappearance kinetics of soybean meal in lactating dairy cows ${ }^{1}$

\begin{tabular}{|c|c|c|c|c|c|c|c|c|}
\hline \multirow[b]{2}{*}{ Item } & \multicolumn{2}{|c|}{$-\mathrm{EO}$} & \multicolumn{2}{|c|}{$+\mathrm{EO}$} & \multirow[b]{2}{*}{ SEM } & \multicolumn{3}{|c|}{ Contrast $^{2}(P=)$} \\
\hline & $-\mathrm{MO}$ & $+\mathrm{MO}$ & $-\mathrm{MO}$ & $+\mathrm{MO}$ & & $\mathrm{EO}$ & MO & Inter \\
\hline \multicolumn{9}{|l|}{ DM } \\
\hline $\mathrm{a}, \%$ & 36.9 & 36.7 & 37.1 & 36.7 & 0.4 & 0.73 & 0.58 & 0.89 \\
\hline$b, \%$ & 62.7 & 62.8 & 62.4 & 63.0 & 0.6 & 0.92 & 0.63 & 0.61 \\
\hline c, $\% / \mathrm{h}$ & 6.31 & 7.11 & 6.40 & 7.02 & 0.33 & 0.99 & 0.08 & 0.79 \\
\hline $\mathrm{L}, \mathrm{h}$ & 1.58 & 1.54 & 1.78 & 1.54 & 0.28 & 0.74 & 0.63 & 0.73 \\
\hline ERD, \% & 65.9 & 67.9 & 65.9 & 67.3 & 0.6 & 0.88 & 0.04 & 0.81 \\
\hline \multicolumn{9}{|l|}{$\mathrm{CP}$} \\
\hline $\mathrm{a}, \%$ & 17.2 & 16.4 & 18.7 & 17.1 & 0.4 & 0.05 & 0.04 & 0.45 \\
\hline $\mathrm{b}, \%$ & 84.8 & 85.5 & 82.8 & 82.3 & 0.7 & 0.16 & 0.07 & 0.25 \\
\hline $\mathrm{c}, \% / \mathrm{h}$ & 5.26 & 5.91 & 5.76 & 6.08 & 0.15 & 0.07 & 0.02 & 0.30 \\
\hline $\mathrm{L}, \mathrm{h}$ & 1.59 & 1.23 & 2.61 & 1.62 & 0.44 & 0.16 & 0.17 & 0.49 \\
\hline ERD, \% & 52.9 & 55.8 & 52.9 & 55.4 & 1.0 & 0.86 & 0.04 & 0.85 \\
\hline
\end{tabular}

${ }^{1} \mathrm{a}=$ Rapidly degradable fraction; $\mathrm{b}=$ slowly degradable fraction; $\mathrm{c}=$ fractional degradation rate of disappearance of fraction $\mathrm{b} ; \mathrm{L}=\mathrm{lag}$ time; ERD = effective ruminal degradability.

${ }^{2} P$-value for factorial contrasts: essential oils (+EO vs. $\left.-\mathrm{EO}\right)$, monensin (+MO vs. $\left.-\mathrm{MO}\right)$, and the interaction between EO and MO (Inter).

suggesting that molar VFA proportions do not accurately reflect changes in VFA production in the rumen (Van Maanen et al., 1978), as was demonstrated subsequently by Rogers and Davis (1982).

Protozoa counts averaged $4.88 \times 10^{5} / \mathrm{mL}$ and were not affected by the addition of $\mathrm{EO}$ and $\mathrm{MO}$ to the diet (Table 4). Other studies (Benchaar et al., 2003b; McIntosh et al., 2003; Newbold et al., 2004) reported no effects of $\mathrm{EO}$ on the number and composition by genera of the ciliate protozoal populations.

\section{In Sacco Ruminal Degradation Kinetics}

There was no interaction between EO and MO for ruminal degradation kinetics of soybean meal (Table 5 ). The rapidly (a) and the slowly (b) degradable fractions of DM averaged 36.9 and $62.8 \%$, respectively, and they were not affected by additive treatments. The rate of DM degradation (c) tended $(P=0.08)$ to be higher $(7.1 \mathrm{vs} .6 .4 \% / \mathrm{h})$ and the ERD of DM was increased $(67.5$ vs. $65.9 \%$ ) for cows fed MO compared with those not receiving MO. Feeding MO decreased the rapidly degradable fraction (a) of CP of soybean meal (18.0 vs. $16.8 \%)$, whereas feeding EO increased it (17.9 vs. $16.8 \%)$. The slowly degradable fraction (b) of CP tended $(P=0.07)$ to increase with MO supplementation. The degradation rate of $\mathrm{CP}$ was higher with than without MO $(6.0$ vs. $5.5 \% / \mathrm{h})$ and tended $(P=0.07)$ to increase slightly for cows fed EO as compared with those fed no EO (5.9 vs. $5.6 \% / \mathrm{h}$ ). The ERD of CP was higher for diets containing MO than for diets not supplemented with MO (55.6 vs. $53.0 \%$ ). Although some changes were noted in the kinetics of in sacco degradation of soybean meal in the rumen of cows supplemented with MO, these changes were too small to have any significant nutritional impact on ruminal N metabolism. Similarly, the kinetics of degradation of soybean meal protein were not changed in growing heifers (Molero et al., 2004) and sheep (Newbold et al., 2004) supplemented with 700 and $110 \mathrm{mg}$ of the EO mixture (Crina Ruminants), respectively.

There was no interaction between EO and $\mathrm{MO}$ on the ruminal degradation kinetics of corn grain (Table 6). The addition of EO had no effect on degradation kinetics and ERD of DM. The addition of MO did not affect the rapidly degradable fraction of $\mathrm{DM}(33.7 \%)$, but it tended $(P=0.09)$ to decrease the slowly degradable fraction of DM of corn (64.4 vs. $65.7 \%$ ) and increased the degradation rate of $\mathrm{DM}(6.0$ vs. $5.4 \% / \mathrm{h})$ compared with when no MO was fed. The ERD of DM of corn tended $(P=$ $0.07)$ to increase for cows fed diets supplemented with MO (66.2 vs. $64.0 \%)$. The ruminal degradation kinetics and ERD of corn starch were not affected by the addition of EO or MO to the diet. Similarly, Surber and Bowman (1998) reported no effect of MO on the degradation rate or the ERD of corn grain.

There was no interaction between EO and MO for the ruminal degradation kinetics of grass silage (Table 7). The rapidly degradable fraction (a), the slowly degradable fraction (b), the rate of disappearance (c) of fraction $b$, the lag time (L), and the ERD of DM were not different among treatments. Similarly, supplementation with $\mathrm{EO}$ and $\mathrm{MO}$ had no effect on the kinetics of ruminal degradation of $\mathrm{ADF}$ and NDF. Although ADF total-tract digestibility was increased by feeding EO (Table 3), results from ruminal in sacco incubations indicated that degradation of $\mathrm{ADF}$ and NDF from grass silage was not affected by EO supplementation. These results suggest that cellulolytic bacterial populations in the rumen were not sensitive to the amount or the 
Table 6. Effects of essential oils (EO) and monensin (MO) on the in sacco ruminal disappearance kinetics of corn grain in lactating dairy cows ${ }^{1}$

\begin{tabular}{|c|c|c|c|c|c|c|c|c|}
\hline \multirow[b]{2}{*}{ Item } & \multicolumn{2}{|c|}{$-\mathrm{EO}$} & \multicolumn{2}{|c|}{$+\mathrm{EO}$} & \multirow[b]{2}{*}{ SEM } & \multicolumn{3}{|c|}{ Contrast $^{2}(P=)$} \\
\hline & $-\mathrm{MO}$ & $+\mathrm{MO}$ & $-\mathrm{MO}$ & $+\mathrm{MO}$ & & EO & MO & Inter \\
\hline \multicolumn{9}{|l|}{ DM } \\
\hline a, $\%$ & 33.5 & 33.8 & 33.3 & 34.2 & 0.4 & 0.69 & 0.16 & 0.51 \\
\hline $\mathrm{b}, \%$ & 65.9 & 64.5 & 65.4 & 64.6 & 0.6 & 0.73 & 0.09 & 0.61 \\
\hline $\mathrm{c}, \% / \mathrm{h}$ & 5.32 & 6.03 & 5.50 & 5.97 & 0.25 & 0.81 & 0.05 & 0.63 \\
\hline $\mathrm{L}, \mathrm{h}$ & 0.30 & 0.60 & 0.42 & 1.04 & 0.32 & 0.41 & 0.20 & 0.64 \\
\hline ERD, \% & 64.3 & 66.0 & 64.6 & 66.3 & 0.8 & 0.75 & 0.07 & 0.99 \\
\hline \multicolumn{9}{|l|}{ Starch } \\
\hline $\mathrm{a}, \%$ & 32.5 & 32.9 & 32.1 & 31.8 & 0.8 & 0.39 & 0.92 & 0.68 \\
\hline $\mathrm{b}, \%$ & 69.6 & 68.5 & 69.5 & 69.8 & 1.1 & 0.61 & 0.75 & 0.57 \\
\hline c, $\% / \mathrm{h}$ & 6.23 & 6.68 & 6.64 & 6.67 & 0.39 & 0.60 & 0.54 & 0.63 \\
\hline $\mathrm{L}, \mathrm{h}$ & 0.00 & 0.00 & 0.06 & 0.06 & 0.04 & 0.21 & 0.98 & 0.98 \\
\hline ERD, \% & 67.7 & 68.8 & 68.6 & 68.6 & 0.9 & 0.71 & 0.57 & 0.57 \\
\hline
\end{tabular}

${ }^{1} \mathrm{a}=$ Rapidly degradable fraction; $\mathrm{b}=$ slowly degradable fraction; $\mathrm{c}=$ fractional degradation rate of disappearance of fraction $\mathrm{b} ; \mathrm{L}=$ lag time; $\mathrm{ERD}=$ effective ruminal degradability.

${ }^{2} P$-value for factorial contrasts: essential oils (+EO vs. $\left.-\mathrm{EO}\right)$, monensin (+MO vs. $\left.-\mathrm{MO}\right)$, and the interaction between $\mathrm{EO}$ and MO (Inter).

mixture of EO used. In fact, Benchaar et al. (2003a) observed no effect of EO supplementation on counts of ruminal cellulolytic bacteria in dairy cows.

The lack of any significant effect of MO addition on apparent digestibilities of NDF and ADF (Table 3) would agree with the similar in sacco ruminal degradation of fiber from grass silage observed for cows supplemented or not supplemented with MO.

\section{Milk Production and Milk Composition}

Production of milk averaged $33.6 \mathrm{~kg} / \mathrm{d}$ and was not affected by additives (Table 8 ). However, $4 \%$ FCM yield tended $(P=0.06)$ to be affected differently by $\mathrm{EO}$ and $\mathrm{MO}$, as shown by a trend for an interaction between $\mathrm{EO}$ and MO. The yield of $4 \% \mathrm{FCM}$ decreased when cows were fed EO alone, whereas it increased when cows

Table 7. Effects of essential oils (EO) and monensin (MO) on the in sacco ruminal disappearance kinetics of grass silage in lactating dairy cows ${ }^{1}$

\begin{tabular}{|c|c|c|c|c|c|c|c|c|}
\hline \multirow[b]{2}{*}{ Item } & \multicolumn{2}{|c|}{$-\mathrm{EO}$} & \multicolumn{2}{|c|}{$+\mathrm{EO}$} & \multirow[b]{2}{*}{ SEM } & \multicolumn{3}{|c|}{ Contrast $^{2}(P=)$} \\
\hline & $-\mathrm{MO}$ & $+\mathrm{MO}$ & $-\mathrm{MO}$ & $+\mathrm{MO}$ & & EO & MO & Inter \\
\hline \multicolumn{9}{|l|}{ DM } \\
\hline$a, \%$ & 39.9 & 39.6 & 39.6 & 39.5 & 0.2 & 0.37 & 0.46 & 0.69 \\
\hline $\mathrm{b}, \%$ & 31.7 & 32.1 & 31.8 & 32.2 & 0.4 & 0.86 & 0.30 & 0.94 \\
\hline $\mathrm{c}, \% / \mathrm{h}$ & 6.86 & 7.39 & 6.74 & 6.80 & 0.57 & 0.56 & 0.62 & 0.69 \\
\hline $\mathrm{L}, \mathrm{h}$ & 2.50 & 2.15 & 2.56 & 1.91 & 0.42 & 0.83 & 0.27 & 0.73 \\
\hline ERD, \% & 56.4 & 57.2 & 56.2 & 56.4 & 0.7 & 0.51 & 0.52 & 0.73 \\
\hline \multicolumn{9}{|l|}{$\mathrm{ADF}$} \\
\hline $\mathrm{a}, \%$ & 13.2 & 12.4 & 13.2 & 13.1 & 0.4 & 0.41 & 0.29 & 0.41 \\
\hline b, \% & 40.5 & 40.0 & 39.5 & 40.2 & 0.8 & 0.61 & 0.86 & 0.45 \\
\hline $\mathrm{c}, \% / \mathrm{h}$ & 5.03 & 6.34 & 4.61 & 5.23 & 0.67 & 0.29 & 0.19 & 0.62 \\
\hline $\mathrm{L}, \mathrm{h}$ & 2.86 & 3.15 & 2.45 & 2.21 & 0.70 & 0.37 & 0.97 & 0.72 \\
\hline ERD, \% & 31.3 & 32.3 & 30.3 & 31.5 & 1.1 & 0.46 & 0.35 & 0.93 \\
\hline \multicolumn{9}{|l|}{$\mathrm{NDF}$} \\
\hline$a, \%$ & 16.7 & 16.0 & 16.6 & 16.7 & 0.5 & 0.61 & 0.54 & 0.44 \\
\hline $\mathrm{b}, \%$ & 37.3 & 37.3 & 36.6 & 37.9 & 0.9 & 0.92 & 0.49 & 0.53 \\
\hline $\mathrm{c}, \% / \mathrm{h}$ & 4.66 & 5.84 & 4.49 & 4.63 & 0.59 & 0.29 & 0.30 & 0.41 \\
\hline $\mathrm{L}, \mathrm{h}$ & 2.77 & 2.82 & 3.62 & 2.05 & 0.63 & 0.95 & 0.27 & 0.24 \\
\hline ERD, \% & 32.6 & 33.8 & 32.1 & 32.9 & 1.0 & 0.51 & 0.37 & 0.89 \\
\hline
\end{tabular}

${ }^{1} \mathrm{a}=$ Rapidly degradable fraction; $\mathrm{b}=$ slowly degradable fraction; $\mathrm{c}=$ fractional degradation rate of disappearance of fraction $\mathrm{b} ; \mathrm{L}=$ lag time; ERD = effective ruminal degradability.

${ }^{2} P$-value for factorial contrasts: essential oils (+EO vs. $\left.-\mathrm{EO}\right)$, monensin (+MO vs. $\left.-\mathrm{MO}\right)$, and the interaction between $\mathrm{EO}$ and $\mathrm{MO}$ (Inter). 
Table 8. Effects of essential oils (EO) and monensin (MO) on the milk production and milk composition of dairy cows

\begin{tabular}{|c|c|c|c|c|c|c|c|c|}
\hline \multirow[b]{2}{*}{ Item } & \multicolumn{2}{|c|}{$-\mathrm{EO}$} & \multicolumn{2}{|c|}{$+\mathrm{EO}$} & \multirow[b]{2}{*}{ SEM } & \multicolumn{3}{|c|}{ Contrast $^{1}(P=)$} \\
\hline & $-\mathrm{MO}$ & $+\mathrm{MO}$ & $-\mathrm{MO}$ & $+\mathrm{MO}$ & & EO & MO & Inter \\
\hline Milk production, kg/d & 34.4 & 34.1 & 32.1 & 34.0 & 0.9 & 0.19 & 0.38 & 0.23 \\
\hline $4 \% \mathrm{FCM},{ }^{2} \mathrm{~kg} / \mathrm{d}$ & 35.0 & 32.9 & 31.7 & 33.7 & 0.8 & 0.22 & 0.76 & 0.06 \\
\hline \multicolumn{9}{|l|}{ Milk composition, \% } \\
\hline Fat & 4.07 & 3.77 & 4.00 & 3.91 & 0.07 & 0.61 & 0.03 & 0.18 \\
\hline Protein & 3.58 & 3.51 & 3.62 & 3.46 & 0.06 & 0.93 & 0.11 & 0.51 \\
\hline Lactose & 4.68 & 4.63 & 4.59 & 4.66 & 0.04 & 0.40 & 0.78 & 0.18 \\
\hline Total solids & 13.0 & 12.6 & 12.9 & 12.8 & 0.1 & 0.96 & 0.04 & 0.19 \\
\hline Milk urea N, mM & 11.8 & 13.0 & 12.3 & 12.2 & 0.3 & 0.64 & 0.06 & 0.05 \\
\hline \multicolumn{9}{|l|}{ Milk yield, kg/d } \\
\hline Fat & 1.41 & 1.28 & 1.28 & 1.34 & 0.03 & 0.26 & 0.28 & 0.03 \\
\hline Protein & 1.23 & 1.18 & 1.15 & 1.17 & 0.05 & 0.37 & 0.75 & 0.49 \\
\hline Lactose & 1.61 & 1.59 & 1.48 & 1.58 & 0.05 & 0.20 & 0.40 & 0.21 \\
\hline Total solids & 4.49 & 4.30 & 4.12 & 4.34 & 0.12 & 0.22 & 0.91 & 0.13 \\
\hline
\end{tabular}

were fed the diet containing both additives. This would suggest that MO supplementation contributes to lessening the negative effect of EO on $4 \%$ FCM yield. Very little work has been published to date on the effects of EO supplementation on the milk performance of dairy cows. Benchaar et al. (2003b) observed no change in milk production when cows were supplemented with $750 \mathrm{mg} / \mathrm{d}$ of EO mixture (Crina Ruminants).

The addition of MO to the diet did not affect milk production, which agrees with the results of Ramanzin et al. (1997) and Broderick (2004). However, Ruiz et al. (2001) observed an increase in milk production when cows were fed MO. Phipps et al. (2000) supplemented $\mathrm{MO}(150,300$, and $450 \mathrm{mg} / \mathrm{d})$ for $19 \mathrm{wk}$ in one trial and from wk 3 to 8 prepartum through 32 wk after calving in 2 consecutive lactations in a second trial $(300 \mathrm{mg} /$ d). In trial 1, Phipps et al. (2000) obtained an increased milk yield at doses of 150 (i.e., $8 \mathrm{mg} / \mathrm{kg}$ of $\mathrm{DM}$ ) and 300 $\mathrm{mg} / \mathrm{d}(16 \mathrm{mg} / \mathrm{kg}$ of DM) but not at the dose of $450 \mathrm{mg} /$ $\mathrm{d}$ (i.e., $24 \mathrm{mg} / \mathrm{kg}$ of DM). However, in the second trial, feeding $\mathrm{MO}$ at $300 \mathrm{mg} / \mathrm{d}$ over 2 consecutive lactations had no influence on milk production. The reasons for discrepancies between studies are difficult to explain but could be related to differences in dietary levels of MO inclusion, stage of lactation, feed intake, diet composition, and length of the trial. More long-term studies are required to evaluate the effect of MO supplementation on milk production in lactating dairy cows.

Milk protein and lactose concentrations averaged, respectively, 3.5 and $4.6 \%$, and were unaffected by EO and MO addition. Very little work has been published on the effects of $\mathrm{EO}$ on milk composition in dairy cows. Benchaar et al. (2003b) reported no effect of EO (750 $\mathrm{mg} / \mathrm{d}$; Crina Ruminants) supplementation on milk composition.
Monensin supplementation had no influence on the milk protein content but decreased the milk fat concentration. Similarly, Sauer et al. (1998) reported a reduction in milk fat content following MO supplementation with no change in milk protein concentration, whereas Ramanzin et al. (1997) observed that feeding MO had no effect on milk concentrations of protein and fat. Conversely, concentrations of protein and fat in milk were decreased when MO was fed to dairy cows (Phipps et al., 2000; Ruiz et al., 2001; Broderick, 2004). In many of the studies in which $\mathrm{MO}$ reduced milk fat and protein concentrations, a parallel increase in milk production was observed, thus suggesting that a dilution effect was partly responsible for changes in milk composition (Phipps et al., 2000), although this was not the case in the current study.

The milk urea $\mathrm{N}$ concentration was increased by MO supplementation, but this effect was not apparent when MO was fed in combination with EO, as shown by the interaction $(P=0.05)$ between EO and MO. A higher milk urea $\mathrm{N}$ concentration has also been reported when cows were supplemented with MO (Duffield et al., 1998). According to Duffield et al. (1998), MO supplementation increases the amount of protein reaching the small intestine and the use of AA for gluconeogenesis (Plaizier et al., 2000), thus increasing deamination and the concentration of blood urea N. On the other hand, the addition of MO to the diet did not change the urea $\mathrm{N}$ concentration in milk (Ruiz et al., 2001). In general, yields of milk components were not changed by addition of additives to the diet, although there was an interaction $(P<0.05)$ between EO and MO for fat yield, which would agree with the results observed for the yield of $4 \% \mathrm{FCM}$. 
Table 9. Effects of essential oils (EO) and monensin (MO) on the fatty acid (FA) profile (g/100 g of FA) of milk fat of dairy cows

\begin{tabular}{|c|c|c|c|c|c|c|c|c|}
\hline \multirow[b]{2}{*}{ Item } & \multicolumn{2}{|c|}{$-\mathrm{EO}$} & \multicolumn{2}{|c|}{$+\mathrm{EO}$} & \multirow[b]{2}{*}{ SEM } & \multicolumn{3}{|c|}{ Contrast $^{1}(P=)$} \\
\hline & $-\mathrm{MO}$ & $+\mathrm{MO}$ & $-\mathrm{MO}$ & $+\mathrm{MO}$ & & EO & $\mathrm{MO}$ & Inter \\
\hline $4: 0$ & 2.35 & 2.19 & 2.39 & 2.39 & 0.10 & 0.31 & 0.47 & 0.48 \\
\hline $6: 0$ & 1.74 & 1.60 & 1.72 & 1.69 & 0.06 & 0.63 & 0.21 & 0.44 \\
\hline $8: 0$ & 1.29 & 1.20 & 1.26 & 1.23 & 0.04 & 0.93 & 0.19 & 0.49 \\
\hline $10: 0$ & 3.39 & 3.17 & 3.27 & 3.22 & 0.09 & 0.73 & 0.17 & 0.40 \\
\hline $12: 0$ & 4.26 & 4.06 & 4.14 & 4.10 & 0.08 & 0.59 & 0.17 & 0.37 \\
\hline 14:0 & 12.44 & 12.18 & 12.08 & 12.18 & 0.08 & 0.08 & 0.37 & 0.08 \\
\hline $14: 1$ & 1.30 & 1.28 & 1.26 & 1.32 & 0.04 & 0.92 & 0.65 & 0.34 \\
\hline $15: 0$ & 1.34 & 1.53 & 1.48 & 1.47 & 0.07 & 0.55 & 0.22 & 0.18 \\
\hline $16: 0$ & 33.26 & 33.35 & 33.39 & 33.93 & 0.44 & 0.45 & 0.50 & 0.62 \\
\hline $16: 1$ & 1.64 & 1.74 & 1.68 & 1.77 & 0.04 & 0.45 & 0.08 & 0.87 \\
\hline $17: 0$ & 0.62 & 0.69 & 0.65 & 0.63 & 0.01 & 0.34 & 0.09 & 0.03 \\
\hline $17: 1$ & 0.18 & 0.20 & 0.20 & 0.19 & 0.01 & 0.49 & 0.49 & 0.19 \\
\hline $18: 0$ & 9.58 & 9.27 & 9.18 & 8.68 & 0.31 & 0.17 & 0.24 & 0.76 \\
\hline trans-10 18:1 & 0.37 & 0.41 & 0.35 & 0.43 & 0.01 & 1.00 & $<0.01$ & 0.20 \\
\hline trans-11 18:1 & 0.64 & 0.75 & 0.67 & 0.77 & 0.04 & 0.47 & 0.03 & 0.95 \\
\hline cis-9 18:1 & 17.20 & 17.57 & 17.63 & 16.86 & 0.33 & 0.69 & 0.55 & 0.13 \\
\hline Other $18: 1$ & 2.95 & 3.20 & 3.00 & 3.40 & 0.13 & 0.37 & 0.04 & 0.57 \\
\hline $18: 2$ & 2.12 & 2.16 & 2.21 & 2.16 & 0.07 & 0.54 & 0.98 & 0.54 \\
\hline 18:3 & 0.37 & 0.40 & 0.38 & 0.39 & 0.02 & 1.00 & 0.29 & 0.62 \\
\hline CLA $^{2}$ & 0.32 & 0.37 & 0.37 & 0.44 & 0.03 & 0.10 & 0.12 & 0.82 \\
\hline Unknown & 2.65 & 2.71 & 2.71 & 2.79 & 0.04 & 0.16 & 0.17 & 0.82 \\
\hline
\end{tabular}

${ }^{1} P$-value for factorial contrasts: essential oils (+EO vs. $\left.-\mathrm{EO}\right)$, monensin (+MO vs. $\left.-\mathrm{MO}\right)$, and the interaction between essential oils and monensin (Inter).

${ }^{2}$ Conjugated linoleic acid: cis-9,trans-11 18:2.

Essential oils from plant extracts have been reported to have an antibacterial activity against gram-negative and gram-positive bacteria (Helander et al., 1998). Several of the gram-positive bacteria are involved in ruminal biohydrogenation of FA (Bauman et al., 1999), thus suggesting that feeding EO could lower biohydrogenation of FA because of a decrease in the number of bacteria involved in that process. Therefore, we were interested in evaluating whether the milk FA profile could be altered by feeding EO to dairy cows. However, the addition of EO had only minor effects on the milk FA profile (Table 9). The concentration of 14:0 was lower when cows were fed EO alone, but this effect was not apparent when EO was fed in combination with MO, as shown by the trend $(P=0.08)$ for the interaction between EO and MO. Feeding MO alone increased the concentration of 17:0, but this effect was not apparent when MO was administered in the presence of $\mathrm{EO}$, which resulted in an interaction $(P<0.05)$ between $\mathrm{EO}$ and MO. The milk concentration of CLA tended $(P=$ $0.10)$ to increase $(+17 \%)$ in cows fed EO compared with those not supplemented with EO. More investigation is needed to assess the potential of using plant extract compounds to alter biohydrogenation of $\mathrm{FA}$ in the rumen.

Feeding MO had slightly more effects on the milk FA profile than feeding EO. Cows fed MO produced milk with greater concentrations of trans-10 18:1 (+17\%) and trans-11 18:1 (+16\%). Jenkins et al. (2003) reported that addition of $25 \mathrm{ppm}$ of MO in continuous cultures of ruminal bacteria increased the concentration of trans-10 18:1 but had no effect on the concentration of trans-11 18:1. Increased concentration of trans-10 18:1 in milk has been associated with decreased milk fat concentration (Griinari et al., 1998), thus explaining the lower milk fat content observed in the current study for cows fed diets supplemented with MO (Table 8). The proportion of $16: 1$ tended $(P=0.08)$ to increase $(+6 \%)$ in milk fat of cows fed MO compared with those fed no MO. The concentration of CLA in milk fat was similar for cows supplemented or not with $\mathrm{MO}$, which would agree with the results of Mutsvangwa et al. (2003). There have been some suggestions that MO can modify milk FA profile by inhibiting biohydrogenation of linoleic acid (18:2) and increasing the content of monounsaturated 18:1 FA (Fellner et al., 1997; Sauer et al., 1998). Fellner et al. (1997) observed higher concentrations of linoleic acid (18:2), trans 18:1, and CLA in continuous cultures of ruminal bacteria following infusion of ionophores (MO, migericin, or tetronasin). Feeding MO had similar effects on enhancing 18:2 and trans FA in the milk of lactating cows (Sauer et al., 1998). Similar increases in trans FA concentration following MO supplementation were observed in the present experiment although there was no difference in 18:2 concentration. Jenkins et al. (2003) suggested that MO increased the concentration of unsaturated FA (e.g., 18:2) in the rumen when the diet contained grains with higher rates 
of ruminal digestion such as barley as compared with corn. In the present study, corn (grain and silage) was the main source of starch (Table 1), thus explaining the lack of effect of MO on the concentrations of 18:2 and 18:3 in milk fat.

\section{CONCLUSIONS}

Results from the present study do not confirm the beneficial effects of EO on rumen metabolism reported in recent short-term in vitro studies. At the concentrations evaluated under the experimental conditions of the current study, EO (2 g/cow per d) and MO (350 $\mathrm{mg} / \mathrm{cow}$ per d) had small effects on digestion, ruminal fermentation characteristics, milk production, and milk composition. Apparent total-tract digestibility of $\mathrm{CP}$ was not changed by EO addition, but was higher for cows fed MO compared with those fed no MO. Ruminal $\mathrm{pH}$ was increased by the addition of EO to the diet. Ruminal ammonia nitrogen concentration was not affected by EO supplementation but was decreased when diets were supplemented with MO. No effect of EO and MO was observed on ruminal total VFA concentration and molar proportions of individual VFA. The addition of EO did not affect milk composition, including the milk FA profile. Concentrations of fat and urea $\mathrm{N}$ in milk were, respectively, lower and higher for cows fed MO as compared with cows fed diets without MO. The reduced milk fat concentration in cows fed MO was associated with the higher level of trans-10 18:1, a potent inhibitor of milk fat synthesis. Although EO have been shown to favorably alter ruminal fermentation in vitro at high doses, further research is required to validate their efficacy in vivo at more normal feeding doses.

\section{ACKNOWLEDGMENTS}

This project was financially supported by the Dairy Farmers of Nova Scotia (Truro, Nova Scotia, Canada), IDENA-Canada (Montreal, Quebec, Canada), the Milk Marketing Board of Prince Edward Island (Charlottetown Prince Edward Island, Canada), Technology Development 2000 Program-Nova Scotia, and Agriculture and Agri-Food Canada (Matching Investment Initiative). The authors are grateful to S. Methot for his help with statistics and to D. Bournival, L. Veilleux, and S. Provencher for technical assistance.

\section{REFERENCES}

AOAC. 1990. Official Methods of Analysis. 15th ed. Association of Official Analytical Chemists International, Arlington, VA.

Ali-Haïmoud, D., M. Vernay, C. Bayourthe, and R. Moncoulon. 1995. Avoparcin and monensin effects on the digestion of nutrients in dairy cows fed a mixed diet. Can. J. Anim. Sci. 75:379-385.
Bauman, D. E., L. H. Baumgard, B. A. Corl, and J. M. Griinari. 1999. Biosynthesis of conjugated linoleic acid in ruminants. Pages 1-5 in Proc. Am. Soc. Anim. Sci. FASS, Savoy, IL. http://www.asas.org/ JAS/symposia/proceedings/ Accessed Nov. 2, 2005.

Benchaar, C., H. V. Petit, R. Berthiaume, D. R. Ouellet, and J. Chiquette. 2003a. Effects of essential oil supplement on ruminal fermentation, rumen microbial populations and in sacco degradation of dry matter and nitrogen in the rumen of lactating dairy cows. Can. J. Anim. Sci. 83:637. (Abstr.)

Benchaar, C., R. Berthiaume, H. V. Petit, D. R. Ouellet, and J. Chiquette. 2003b. Effects of essential oil supplement on nutrient digestibility, nitrogen retention, duodenal bacterial nitrogen flow, milk production and composition in lactating dairy cows. Can. J. Anim. Sci. 83:638. (Abstr.)

Benchaar, C., J. L. Duynisveld, and E. Charmley. 2006. Effects of monensin and increasing dose levels of a mixture of essential oil compounds on intake, digestion and growth performance of beef cattle. Can. J. Anim. Sci. 86:91-96.

Broderick, G. A. 2004. Effect of low level monensin supplementation on the production of dairy cows fed alfalfa silage. J. Dairy Sci. 87:359-368.

Busquet, M., S. Calsamiglia, A. Ferret, and C. Kamel. 2005. Screening for the effects of natural plant extracts and secondary plant metabolites on rumen microbial fermentation in continuous culture. Anim. Feed Sci. Technol. 123-124:597-613.

Busquet, M., S. Calsamiglia, A. Ferret, and C. Kamel. 2006. Plant extracts affect in vitro rumen microbial fermentation. J. Dairy Sci. 89:761-771.

Cardozo, P. W., S. Calsamiglia, A. Ferret, and C. Kamel. 2004. Effects of plant extracts on ruminal protein degradation and fermentation profiles in continuous culture. J. Anim. Sci. 82:3230-3236.

Castillejos, L., S. Calsamiglia, A. Ferrer, and R. Losa. 2005. Effects of a specific blend of essential oil compounds and the type of diet on rumen microbial fermentation and nutrient flow from a continuous culture system. Anim. Feed Sci. Technol. 119:29-41.

CCAC (Canadian Council on Animal Care). 1993. Guide to the Care and Use of Experimental Animals. Vol. 1. E. D. Olfert, B. M. Cross, and A. A. McWilliam, ed. CCAC, Ottawa, Ontario.

Chouinard, P. Y., J. Lévesque, V. Girard, and G. J. Brisson. 1997. Dietary soybeans extruded at different temperatures: Milk composition and in situ fatty acid reactions. J. Dairy Sci. 80:29132924.

Conner, D. E. 1993. Naturally occurring compounds. Pages 441-468 in Antimicrobials in Foods. P. M. Davidson and A. L. Branen, ed. Marcel Dekker, New York, NY.

Duffield, T. F., D. Sandals, K. E. Leslie, K. Lissemore, B. W. McBride, J. H. Lumsden, P. Dick, and R. Bagg. 1998. Effect of prepartum administration of monensin in a controlled-release capsule on postpartum energy indicators in lactating dairy cows. J. Dairy Sci. 81:2354-2361.

Fellner, V., F. D. Sauer, and J. K. G. Kramer. 1997. Effect of nigericin, monensin, and tetronasin on biohydrogenation in continuous flow-through ruminal fermentors. J. Dairy Sci. 80:921-928.

Griinari, J. M., D. A. Dwyer, M. A. McGuire, D. E. Bauman, D. L. Palmquist, and K. V. V. Nurmela. 1998. Trans-octadecenoic acids and milk fat depression in lactating dairy cows. J. Dairy Sci. 81:1251-1261.

Helander, I. M., H. L. Alakomi, K. Latva-Kala, T. Mattila-Sandholm, I. Mol, E. J. Smid, L. G. Gorris, and A. von Wright. 1998. Characterization of the action of selected essential oil components on Gram-negative bacteria. J. Agric. Food Chem. 46:3590-3595.

Hummelbrunner, L. A., and M. B. Isman. 2001. Acute, sublethal, antifeedant, and synergistic effects of monoterpenoid essential oil compounds on the tobacco cutworm, Spodoptera litura (Lep., Noctuidae). J. Agric. Food Chem. 49:715-720.

Jenkins, T. C., V. Fellner, and R. K. McGuffey. 2003. Monensin by fat interactions on trans fatty acids in cultures of mixed ruminal microorganisms grown in continuous fermentors fed corn or barley. J. Dairy Sci. 86:324-330.

Keppler, D., and K. Decker. 1974. Glycogen determination with amyloglucosidase. Pages 1127-1131 in Methods of Enzymatic Analy- 
sis. Vol. 3. Verlag Chemie, Weinham Academic Press, New York, NY.

McDonald, I. 1981. A revised model for the estimation of protein degradability in the rumen. J. Agric. Sci. (Camb.) 96:251-252.

McIntosh, F. M., P. Williams, R. Losa, R. J. Wallace, D. A. Beever, and C. J. Newbold. 2003. Effects of essential oils on ruminal microorganisms and their protein metabolism. Appl. Environ. Microbiol. 69:5011-5014.

Molero, R., M. Ibara, S. Calsamiglia, A. Ferret, and R. Losa. 2004. Effects of a specific blend of essential oil compounds on dry matter and crude protein degradability in heifers fed diets with different forage to concentrate ratios. Anim. Feed Sci. Technol. 114:91-104.

Mutsvangwa, T., J. K. G. Kramer, C. B. Blackadar, T. F. Duffield, R. Bagg, P. Dick, G. Vessie, and B. W. McBride. 2003. Effects of a monensin premix on milk fatty acid content during subacute ruminal acidosis in dairy cows. J. Dairy Sci. 86:4043-4046.

National Research Council. 2001. Nutrient Requirements of Dairy Cattle. 7th rev. ed. Nat. Acad. Press, Washington, DC.

Newbold, C. J., F. M. McIntosh, P. Williams, R. Losa, and R. J. Wallace. 2004. Effects of a specific blend of essential oil compounds on rumen fermentation. Anim. Feed Sci. Technol. 114:105-112.

Ogimoto, K., and S. Imai. 1981. Atlas of Rumen Microbiology. Japan Scientific Societies Press, Tokyo, Japan.

Phipps, R. H., J. I. Wilkinson, L. J. Jonker, M. Tarrant, A. K. Jones, and A. Hodge. 2000. Effect of monensin on milk production of Holstein-Friesian dairy cows. J. Dairy Sci. 83:2789-2794.

Plaizier, J. C., A. Martin, T. Duffield, R. Bagg, P. Dick, and B. W. McBride. 2000. Effect of a prepartum administration of monensin in a controlled-release capsule on apparent digestibilities and nitrogen utilization in transition dairy cows. J. Dairy Sci. 83:2918-2925.

Ramanzin, M., L. Bailoni, S. Schiavon, and G. Bittante. 1997. Effect of monensin on milk production and efficiency of dairy cows fed two diets differing in forage to concentrate ratios. J. Dairy Sci. 80:1136-1142.
Rogers, J. A., and C. L. Davis. 1982. Rumen volatile fatty acid production and nutrient utilization in steers fed a diet supplemented with sodium bicarbonate and monensin. J. Dairy Sci. 65:944-952.

Ruiz, R., G. L. Albrecht, L. O. Tedeschi, G. Jarvis, J. B. Russell, and D. G. Fox. 2001. Effect of monensin on the performance and nitrogen utilization of lactating dairy cows consuming fresh forage. J. Dairy Sci. 84:1717-1727.

Russell, J. B., H. J. Strobel, and G. J. Chen. 1988. Enrichment and isolation of a ruminal bacterium with a very high specific activity of ammonia production. Appl. Environ. Microbiol. 54:872-877.

SAS Institute. 2000. SAS/STAT User's Guide. Release 8.02. SAS Inst. Inc., Cary, NC.

Sauer, F. D., V. Fellner, R. Kinsman, J. K. G. Kramer, H. A. Jackson, A. J. Lee, and S. Chen. 1998. Methane output and lactation response in Holstein cattle with monensin or unsaturated fat added to the diet. J. Anim. Sci. 76:906-914.

Spanghero, M., and Z. M. Kowalski. 1997. Critical analysis of N balance experiments with lactating cows. Livestock Prod. Sci. 52:113-122.

Sukhija, P. S., and D. L. Palmquist. 1988. Rapid method for determination of total fatty acid content and composition of feedstuffs and feces. J. Agric. Food Chem. 36:1202-1206.

Surber, L. M., and J. G. Bowman. 1998. Monensin effects on digestion of corn or barley high-concentrate diets. J. Anim. Sci. 76:19451954

Tedeschi, L. O., D. G. Fox, and T. P. Tylutki. 2003. Potential environmental benefits of ionophores in ruminant diets. J. Environ. Qual. 32:1591-1602.

Van Maanen, R. W., J. H. Herbein, A. D. McGilliard, and J. W. Young. 1978. Effects of monensin on in vivo rumen propionate production and blood glucose kinetics in cattle. J. Nutr. 108:1002-1007.

Van Soest, P. J., J. B. Robertson, and B. A. Lewis. 1991. Carbohydrate methodology, metabolism and nutritional implications in dairy cattle. Methods for dietary fiber, neutral detergent fiber, and nonstarch polysaccharides in relation to animal nutrition. J. Dairy Sci. 74:3583-3597.

Weatherburn, M. W. 1967. Phenol-hypochlorite reaction for determination of ammonia. Anal. Chem. 39:971-974. 